Supporting Information

\title{
Effect of Green Plasticizer on the Performance of Microcrystalline Cellulose/Polylactic Acid Biocomposites
}

Uttam C. Paul, Despina Fragouli, Ilker S. Bayer, Arkadiusz Zych, Athanassia Athanassiou Smart Materials, Istituto Italiano di Tecnologia, Via Morego 30, 16163 Genova, Italy.

Corresponding Author E-mail: athanassia.athanassiou@iit.it 
SEM analysis of microcrystalline cellulose (MCC) and polylactic acid (PLA) powder.

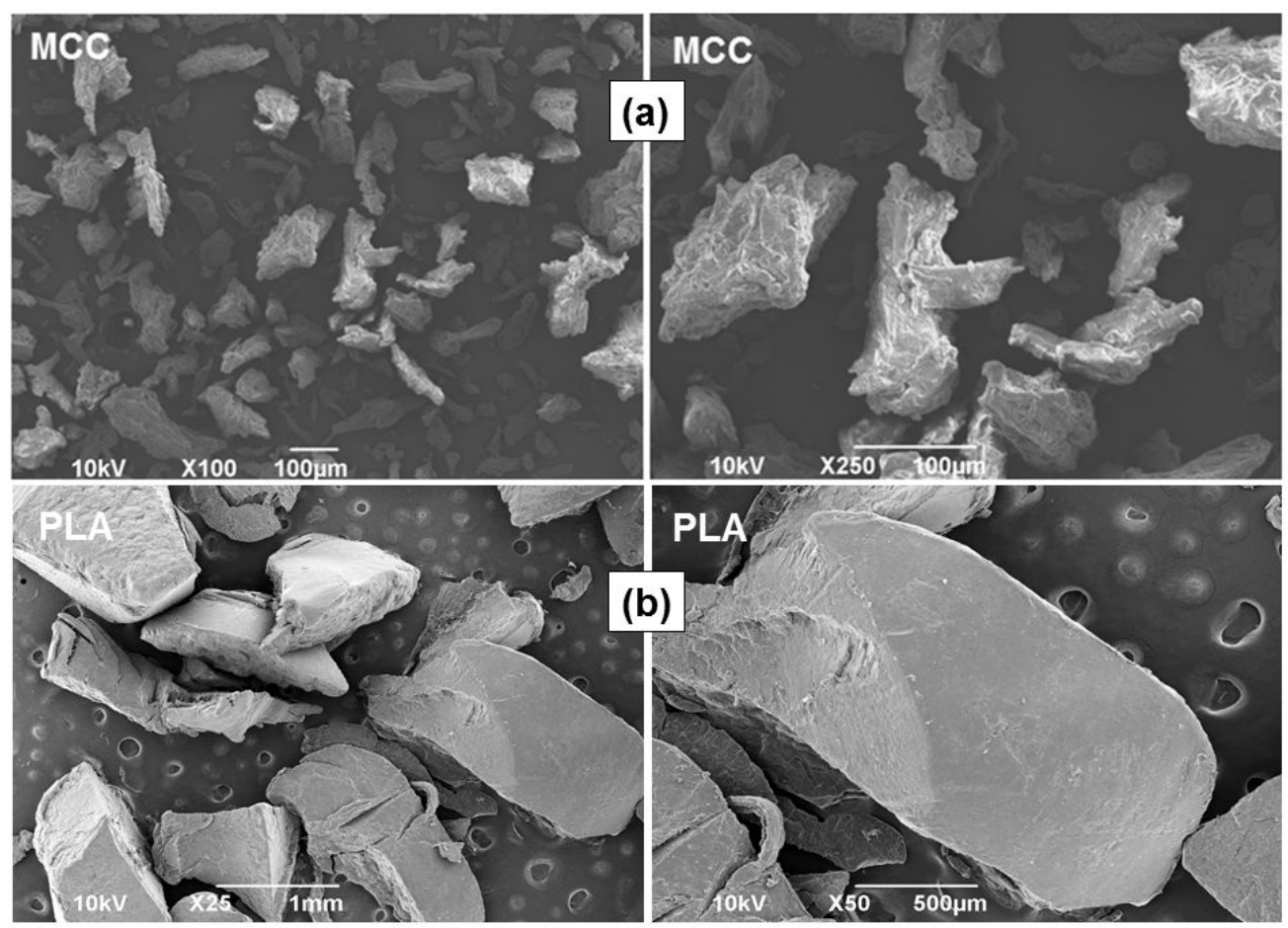

Figure S1. SEM images showing the size ranges of (a) MCC and (b) PLA powder used in this study.

FTIR-ATR analysis of PLA, TEC, and PLA/TEC blends. As shown in Figure S2, and Table S1, the FTIR-ATR analysis proves that PLA, TEC as well as their blends PLA/TEC contain all claimed components. In particular, all films containing PLA, show a characteristic peak around $1750 \mathrm{~cm}^{-1}$ corresponding to the carbonyl stretching vibration $(\mathrm{vC}=\mathrm{O})$ band of PLA. The carbonyl group of pure TEC shows maximum absorption at around $1730 \mathrm{~cm}^{-1}$, and when TEC is combined with the PLA it overlaps with the carbonyl absorption of PLA. 


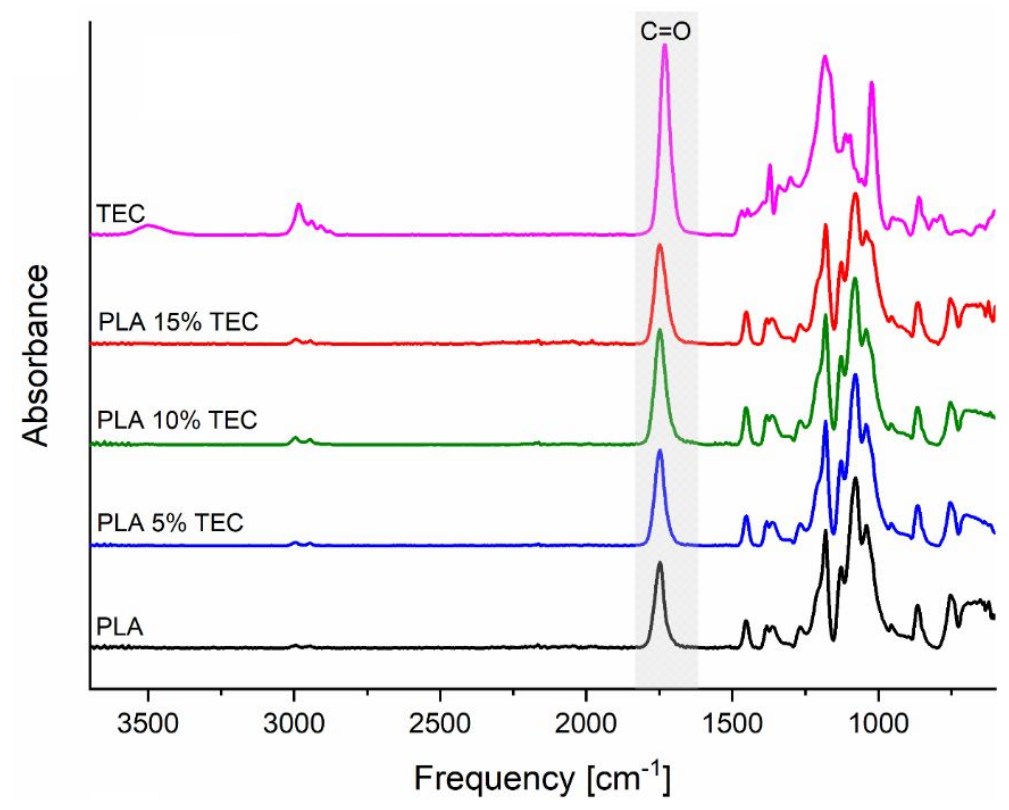

Figure S2. FTIR-ATR spectra of PLA, TEC, and PLA/TEC blends

Table S1. Main chemical functional groups of PLA, PLA/TEC, PLA/MCC, and PLA/MCC_TEC biocomposites.

\begin{tabular}{|c|c|c|c|c|c|c|c|c|c|c|}
\hline & PLA & PLA/TEC 5\% & PLA/TEC $10 \%$ & PLA/TEC $15 \%$ & PLA/MCC & $\begin{array}{c}\text { PLA/MCC } \\
\text { TEC } 5 \%\end{array}$ & $\begin{array}{c}\text { PLA/MCC } \\
\text { TEC } 10 \%\end{array}$ & $\begin{array}{c}\text { PLA/MCC } \\
\text { TEC } 15 \%\end{array}$ & $\mathrm{MCC}$ & TEC \\
\hline $\begin{array}{l}\mathrm{O}-\mathrm{H} \\
{\left[\mathrm{cm}^{-1}\right]}\end{array}$ & - & - & - & - & 3339 & 3341 & 3339 & 3339 & 3333 & - \\
\hline $\begin{array}{l}\mathrm{C}=\mathrm{O} \\
{\left[\mathrm{cm}^{-1}\right]}\end{array}$ & 1748 & 1748 & 1749 & 1749 & 1749 & 1749 & 1751 & 1751 & - & 1730 \\
\hline
\end{tabular}

SEM analysis of PLA and PLA/TEC blend films. From SEM analysis, it can be seen that the surface of PLA and PLA/TEC are both smooth. This indicates that TEC has good compatibility with PLA, Figure S3. From the cross-sectional analysis (Figure S4) it can be seen that with increasing TEC content, the fractured surface becomes smoother. Showing the plasticizing effect of TEC. 


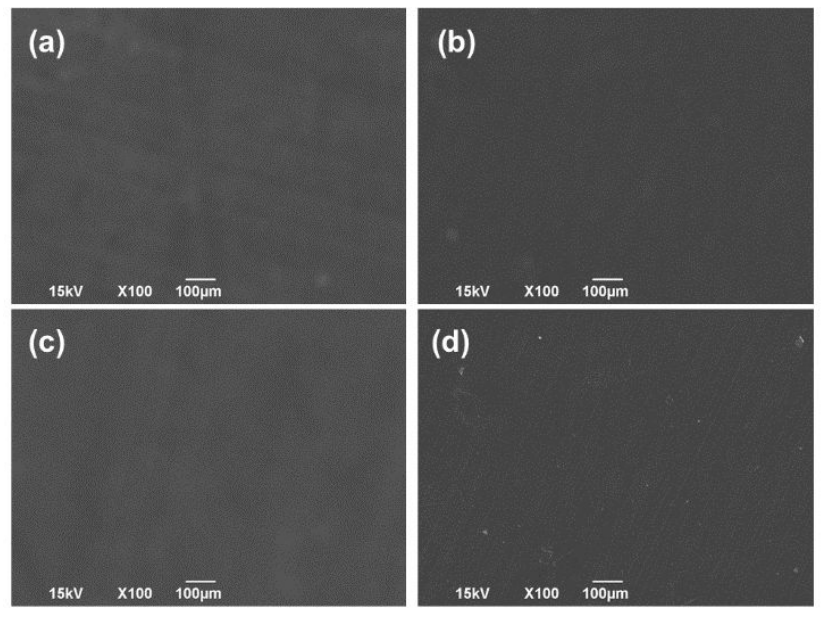

Figure S3. SEM morphology of (a) PLA, (b) PLA/5\%TEC, (c) PLA/10\%TEC, and (d) PLA/15\%TEC films surface.

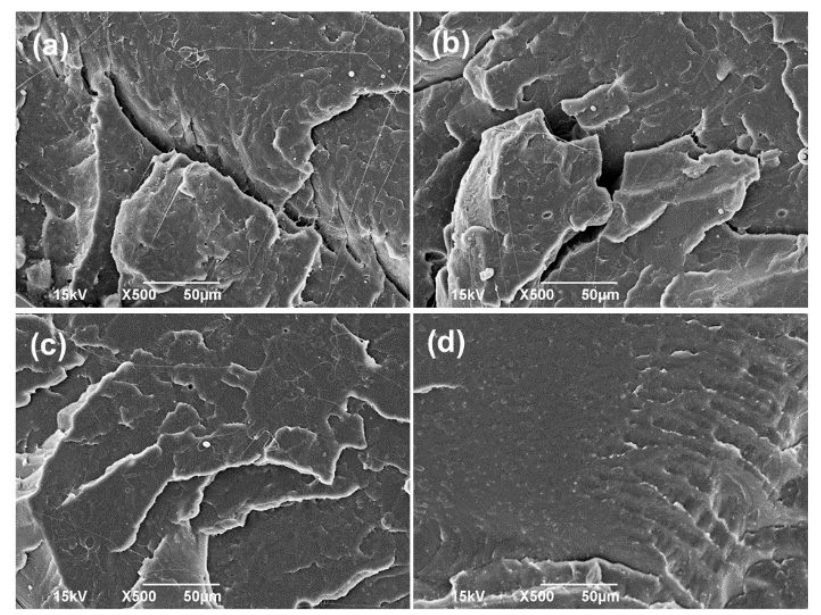

Figure S4. SEM morphology of (a) PLA, (b) PLA/5\%TEC, (c) PLA/10\%TEC, and (d) PLA/15\%TEC films cross-section.

X-ray diffraction (XRD) analysis of PLA and PLA/TEC. As shown in the XRD analysis of Figure S5, the PLA films exhibit only a broad halo diffraction band at $2 \theta=15.8^{0}$ which suggests that the sample is almost fully amorphous ${ }^{1-2}$ The introduction of up to $15 \mathrm{wt} . \%$ TEC did not induce the crystallization of PLA. 


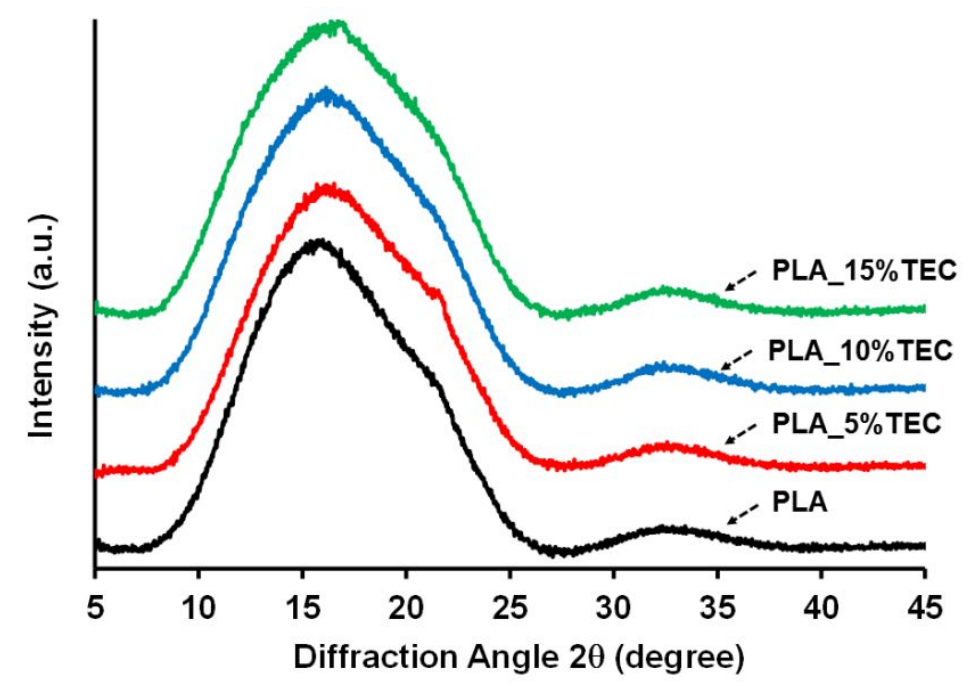

Figure S5. Diffraction patterns of PLA, and PLA/TEC films.

Tensile testing analysis of PLA, PLA/TEC, and PLA/MCC_TEC films. The typical tensile stressstrain curves are presented in Figure S6. From Figure S6, it can be seen that increasing the TEC content increases the tensile strain but decrease the tensile stress. This is due to the plasticization effect of TEC on PLA/TEC and PLA/MCC_TEC samples.
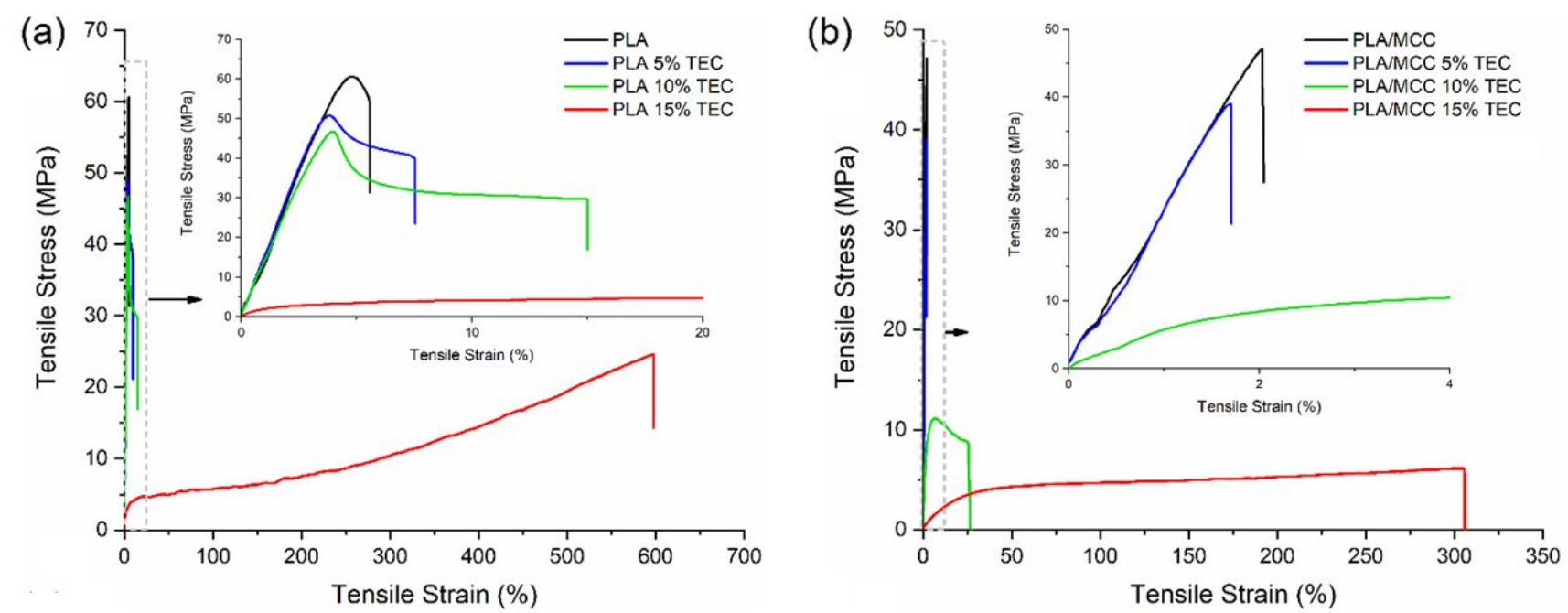

Figure S6. Typical tensile stress-strain curves of (a) PLA and PLA/TEC blend, (b) PLA/MCC, and PLA/MCC_TEC biocomposites. 
Thermal degradation analysis of PLA, MCC, TEC, PLA/TEC, and PLA/MCC_TEC films. After deconvolution of the PLA/MCC curve, it can be seen that PLA/MCC has two distinct decomposition temperatures, attributed to the two polymeric components. These two peaks confirm that there are no strong interactions upon simple mixing of the two polymers. However, the incorporation of TEC into the PLA matrix shows only one decomposition peak both in the case of PLA/TEC blends and PLA/MCC_TEC biocomposites, Figure S7.

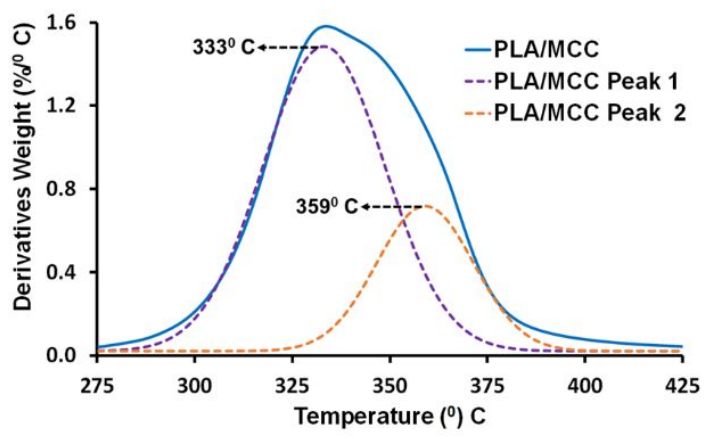

Figure S7. Deconvolution TGA spectra of PLA/MCC biocomposites.
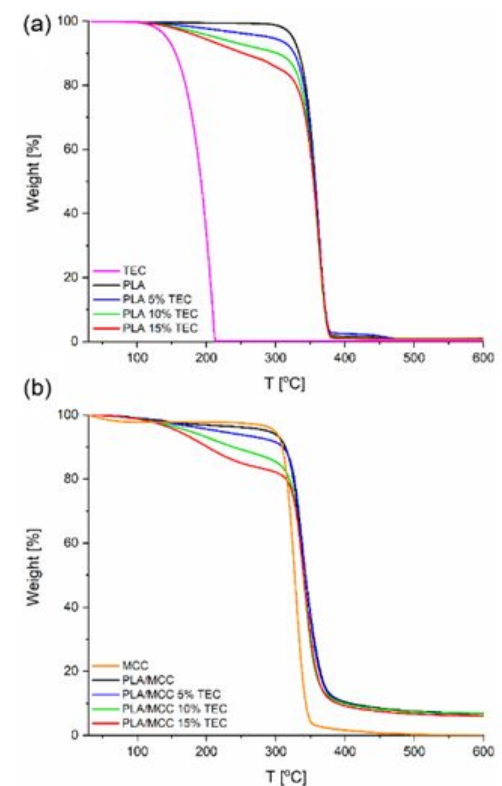

Figure S8. Thermal degradation behavior of (a) TEC, PLA and PLA/TEC blends, (b) MCC, PLA/MCC and PLA/MCC_TEC biocomposites. 


\section{Dynamic water contact angle of PLA/TEC, and PLA/MCC_TEC biocomposites films. From} dynamic water contact angle analysis, it can be seen that there is a big fluctuation of WCA of PLA/MCC film. This can be attributed to the rough surface of the PLA/MCC film. On the contrary, no significant WCA changes were noticed over time for the PLA/MCC_TEC biocomposite samples as shown in Figure S9. This is due to the better mixing and molding of PLA/MCC films in presence of TEC which results in a smooth surface.

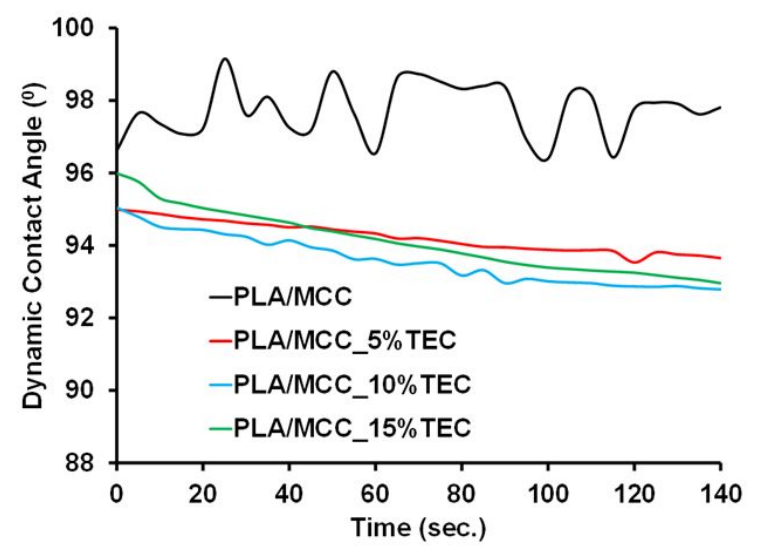

Figure S9. Dynamic water contact angle of PLA/MCC, and PLA/MCC_TEC biocomposite films.

Moisture content analysis of PLA/MCC_TEC films at high RH. To measure the moisture content analysis of the films, an in-house device is used. To do so, the samples were previously conditioned at standard laboratory atmosphere (i.e. $21 \pm 2{ }^{\circ} \mathrm{C}$ and $50 \pm 2 \% \mathrm{RH}$ ) for 14 days. After that, around $200 \mathrm{mg}$ (M0) of each sample was placed in a chamber at RT and $100 \%$ RH for 14 days. Then the samples were weighed again (Mt). The moisture content percentage was then calculated based on the following equation (1). The data reported are average values obtained from three separate samples of each film.

$$
\text { Moisture content }(\%)=\frac{\left(M_{t}-M_{0}\right)}{M_{0}} \times 100
$$




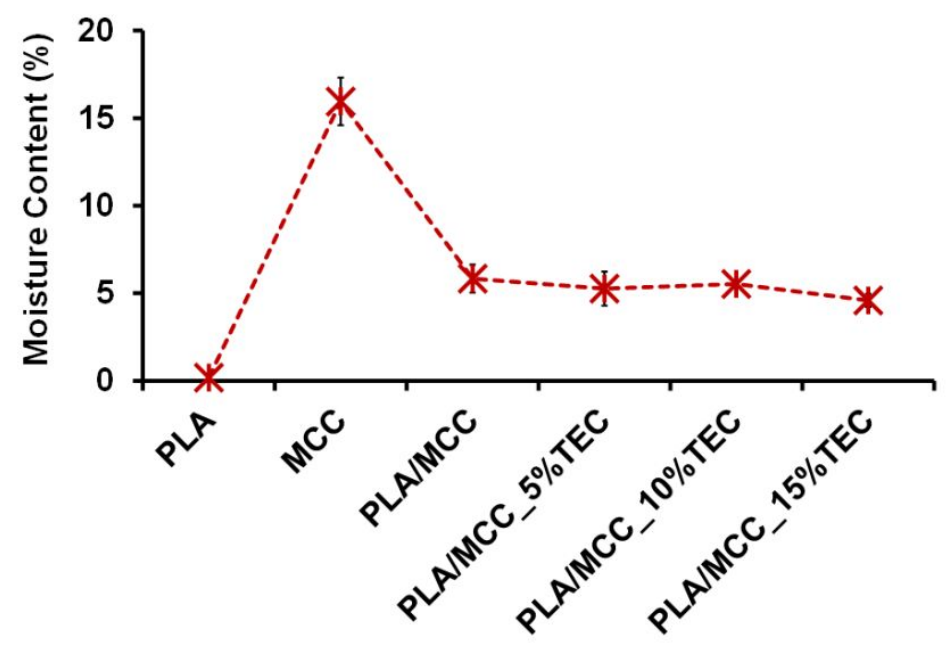

Figure S10. Moisture content analysis of PLA, MCC, PLA/MCC, and PLA/MCC_TEC biocomposite films

Oxygen permeability (OP) values of polymers commonly used for packaging applications. Figure S11 shows the OP values of poly (hydroxybutyrate) (PHB) $\left(11.5 \mathrm{~cm}^{3} \cdot \mathrm{mm} / \mathrm{m}^{2} /\right.$ day), polypropylene (PP) (100 $\mathrm{cm}^{3} \cdot \mathrm{mm} / \mathrm{m}^{2} /$ day), polystyrene (PS) $\left(150 \mathrm{~cm}^{3} \cdot \mathrm{mm} / \mathrm{m}^{2} /\right.$ day), and low density polyethylene (LDPE), $\left(160 \mathrm{~cm}^{3} \cdot \mathrm{mm} / \mathrm{m}^{2} /\right.$ day $) .{ }^{3-5}$

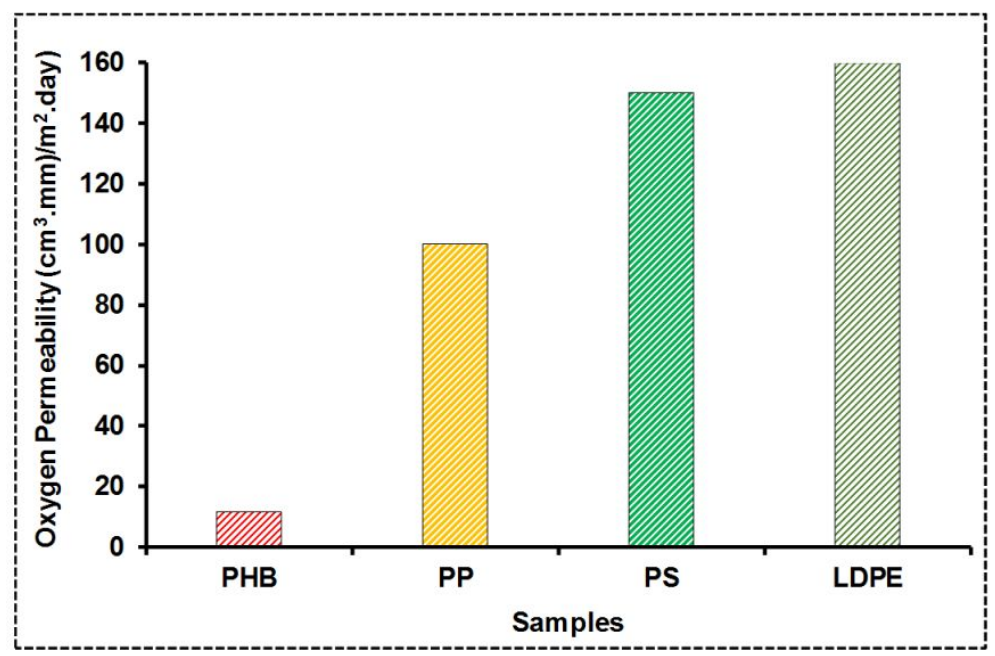

Figure S11. Oxygen permeability (OP) values of polymers commonly used for packaging applications. 
Ranking of biocomposites using TOPSIS. TOPSIS is a multi-criteria decision-making method to identify the best solutions from a finite set of alternatives. The TOPSIS method consists of the following steps.

\section{Step 1: Selection of the decision matrix criteria}

The decision matrix criteria is selected according to the parameters listed in Table S2. In this case, the no. of alternatives are 8 and no. of criteria is 4 .

Table S2. Decision Matrix

\begin{tabular}{ccccc}
\hline Alternative & \multicolumn{3}{c}{ Criteria } \\
\hline & $\begin{array}{c}\text { Elongation } \\
\text { at break }\end{array}$ & $\begin{array}{c}\text { Water vapor } \\
\text { Permeability }\end{array}$ & $\begin{array}{c}\text { Oxygen Permeability } \\
\left(\mathrm{cm}^{3} . \mathrm{mm} / \mathrm{m}^{2} / \text { day }\right)\end{array}$ & $\begin{array}{c}\text { Food Migration } \\
\left(\mathrm{mg} / \mathrm{dm}^{2}\right)\end{array}$ \\
Composites & $(\%)$ & $\left(\mathrm{g} . \mathrm{m} / \mathrm{m}^{2} / \mathrm{day} / \mathrm{Pa}\right)$ & $2.60 \mathrm{E}+01$ & 0.82 \\
PLA & 5.57 & $3.58 \mathrm{E}-05$ & $3.57 \mathrm{E}+01$ & 6.2 \\
PLA/5\%TEC & 9.74 & $4.18 \mathrm{E}-06$ & $1.56 \mathrm{E}+01$ & 9.5 \\
PLA/15\%TEC & 595.19 & $2.03 \mathrm{E}-06$ & $1.64 \mathrm{E}+01$ & 45.10 \\
PLA/MCC & 2.00 & $8.43 \mathrm{E}-05$ & $2.21 \mathrm{E}+03$ & 0.61 \\
PLA/MCC_5\% TEC & 1.70 & $4.78 \mathrm{E}-05$ & $2.38 \mathrm{E}+03$ & 4.68 \\
PLA/MCC_10\% TEC & 25.97 & $1.23 \mathrm{E}-05$ & $6.32 \mathrm{E}+00$ & 7.10 \\
PLA/MCC_15\% TEC & 299.78 & $1.88 \mathrm{E}-05$ & $1.89 \mathrm{E}+01$ & 34.84 \\
\hline
\end{tabular}

Step 2. Calculation of the normalized decision matrix.

The normalized decision matrix value was calculated according to the equation 2 and the values are shown in Table S2.

$$
\overline{X_{i j}}=\frac{X_{i j}}{\sqrt{\sum_{i=1}^{n} X_{i j}^{2}}}
$$


Here, $\mathrm{i}=$ no. of alternatives, and $\mathrm{j}=$ no. of criteria.

Table S3. Normalization Matrix

\begin{tabular}{|c|c|c|c|c|}
\hline Composites & $\begin{array}{c}\text { Elongation } \\
\text { at break } \\
(\%)\end{array}$ & $\begin{array}{c}\text { Water vapor } \\
\text { Permeability } \\
\left(\mathrm{g} . \mathrm{m} / \mathrm{m}^{2} / \text { day } / \mathrm{Pa}\right)\end{array}$ & $\begin{array}{c}\text { Oxygen } \\
\text { Permeability } \\
\left(\mathrm{cm}^{3} \cdot \mathrm{mm} / \mathrm{m}^{2} / \text { day }\right)\end{array}$ & $\begin{array}{c}\text { Food } \\
\text { Migration } \\
\left(\mathrm{mg} / \mathrm{dm}^{2}\right)\end{array}$ \\
\hline PLA & 0.01 & $9.90 \mathrm{E}-01$ & $5.25 \mathrm{E}-01$ & 0.02 \\
\hline PLA/5\%TEC & 0.02 & 0.115652 & 7.19E-01 & 0.13 \\
\hline PLA/10\%TEC & 0.02 & 0.052569 & $3.13 \mathrm{E}-01$ & 0.20 \\
\hline PLA $/ 15 \%$ TEC & 1.00 & 0.056324 & $3.30 \mathrm{E}-01$ & 0.97 \\
\hline $\mathrm{PLA} / \mathrm{MCC}$ & 0.01 & $8.47 \mathrm{E}-01$ & $6.80 \mathrm{E}-01$ & 0.02 \\
\hline PLA/MCC_5\% TEC & 0.01 & $4.81 \mathrm{E}-01$ & $7.34 \mathrm{E}-01$ & 0.13 \\
\hline PLA/MCC_10\% TEC & 0.09 & $1.23 \mathrm{E}-01$ & $1.95 \mathrm{E}-03$ & 0.20 \\
\hline PLA/MCC_15\% TEC & 1.00 & $1.89 \mathrm{E}-01$ & $5.82 \mathrm{E}-03$ & 0.97 \\
\hline
\end{tabular}

\section{Step 3. Calculation of the weighted normalized decision matrix.}

The weighted normalized decision matrix was obtained by equal distribution of weight (25\%) to all the criteria. The weighted normalized value is expressed as Vij, is calculated according to the equation 3 and the values is shown in Table S4.

$$
V_{i j}=X_{i j} \times W_{j}
$$

Where $\mathrm{Wj}$ is weight of each criteria.

Table S4. Weight Normalized Matrix

\begin{tabular}{ccccc}
\hline & $\begin{array}{c}\text { Elongation } \\
\text { at break }\end{array}$ & $\begin{array}{c}\text { Water vapor } \\
\text { Permeability }\end{array}$ & $\begin{array}{c}\text { Oxygen } \\
\text { Permeability }\end{array}$ & $\begin{array}{c}\text { Food } \\
\text { Migration } \\
\text { Composites }\end{array}$ \\
\hline
\end{tabular}




\begin{tabular}{ccccc}
\hline PLA & 0.0023 & 0.2476 & 0.1312 & 0.0044 \\
PLA/5\%TEC & 0.0041 & 0.0289 & 0.1798 & 0.0336 \\
PLA/10\%TEC & 0.0055 & 0.0131 & 0.0784 & 0.0510 \\
PLA/15\%TEC & 0.2499 & 0.0141 & 0.0826 & 0.2424 \\
PLA/MCC & 0.0017 & 0.2118 & 0.1699 & 0.0042 \\
PLA/MCC_5\% TEC & 0.0014 & 0.1203 & 0.1834 & 0.0326 \\
PLA/MCC_10\% TEC & 0.0216 & 0.0308 & 0.0005 & 0.0495 \\
PLA/MCC_15\% TEC & 0.2491 & 0.0471 & 0.0015 & 0.2428 \\
\hline
\end{tabular}

\section{Step 4. Calculation of the ideal best and ideal worst value.}

The ideal best and ideal worst value was selected from weight normalized decision matrix, according to the performance criterial of biocomposites and the values are shown in Table S5.

Table S5. Ideal best and ideal worst solution

\begin{tabular}{|c|c|c|c|c|}
\hline $\begin{array}{l}\text { Composites } \\
\text { PLA/TEC }\end{array}$ & $\begin{array}{c}\text { Elongation } \\
\text { at Break (\%) }\end{array}$ & $\begin{array}{c}\text { Water vapor } \\
\text { Permeability } \\
\text { (g.m/m²/day } / \mathrm{Pa})\end{array}$ & $\begin{array}{c}\text { Oxygen } \\
\text { Permeability } \\
\left(\mathrm{cm}^{3} . \mathrm{mm} / \mathrm{m}^{2} / \text { day }\right)\end{array}$ & $\begin{array}{l}\text { Food Migration } \\
\qquad\left(\mathrm{mg} / \mathrm{dm}^{2}\right)\end{array}$ \\
\hline $\begin{array}{c}\mathrm{V}_{\mathrm{j}}^{+} \text {(ideal best } \\
\text { solution) }\end{array}$ & 0.2499 & 0.0131 & 0.0784 & 0.0044 \\
\hline $\begin{array}{l}\mathrm{V}_{\mathrm{j}}^{-} \text {(ideal worst } \\
\text { solution) }\end{array}$ & 0.0023 & 0.2476 & 0.1798 & 0.2424 \\
\hline $\begin{array}{c}\text { Composites } \\
\text { PLA/MCC_TEC }\end{array}$ & $\begin{array}{c}\text { Elongation } \\
\text { at Break (\%) }\end{array}$ & $\begin{array}{c}\text { Water vapor } \\
\text { Permeability } \\
\text { (g.m/m²/day } / \mathrm{Pa})\end{array}$ & $\begin{array}{c}\text { Oxygen } \\
\text { Permeability } \\
\text { (mL.mm/m²/daya) }\end{array}$ & $\begin{array}{c}\text { Food Migration } \\
\quad\left(\mathrm{mg} / \mathrm{dm}^{2}\right)\end{array}$ \\
\hline $\begin{array}{c}\mathrm{V}_{\mathrm{j}}^{+} \text {(ideal best } \\
\text { solution) }\end{array}$ & 0.2491 & 0.0308 & 0.0005 & 0.0042 \\
\hline $\begin{array}{c}\mathrm{V}_{\mathrm{j}}^{-} \text {(ideal worst } \\
\text { solution) }\end{array}$ & 0.0014 & 0.2118 & 0.1834 & 0.2428 \\
\hline
\end{tabular}


Step 5. Calculation of the separation measure (Euclidean distance from the ideal best and ideal worst).

The separation of each alternative (euclidean distance) can be calculated from the positive and negative ideal solutions as per the following equations ( $4 \& 5)$ and the values are shown in Table S6.

$$
\begin{aligned}
& S_{i}^{+}=\left\lfloor\sum_{j=1}^{m}\left(V_{i j}-V_{j}^{+}\right)^{2}\right\rfloor^{0.5} \\
& S_{i}^{-}=\left\lfloor\sum_{j=1}^{m}\left(V_{i j}-V_{j}^{-}\right)^{2}\right\rfloor^{0.5}
\end{aligned}
$$

Where, $\mathrm{S}_{\mathrm{i}}^{+}$is euclidean distance from the ideal best, and $\mathrm{S}_{\mathrm{i}}^{-}$is euclidean distance from the ideal worst.

Table S6. Separation measure.

\begin{tabular}{ccc}
\hline Composites & $\mathrm{Si}^{+}$ & $\mathrm{Si}^{-}$ \\
\hline PLA & 0.3450 & 0.2429 \\
PLA/5\%TEC & 0.2680 & 0.3024 \\
PLA/10\%TEC & 0.2488 & 0.3192 \\
PLA/15\%TEC & 0.2380 & 0.3539 \\
PLA/MCC & 0.3502 & 0.2390 \\
PLA/MCC_5\% TEC & 0.3219 & 0.2293 \\
PLA/MCC_10\% TEC & 0.2319 & 0.3225 \\
PLA/MCC_15\% TEC & 0.2392 & 0.3486 \\
\hline
\end{tabular}

Step 6. Calculation of the relative closeness to ideal solutions and ranking of biocomposites.

The relative closeness of the biocomposites was calculated from the positive $\left(\mathrm{S}_{\mathrm{i}}{ }^{+}\right)$and negative $\left(\mathrm{S}_{\mathrm{i}}-\right)$ euclidean distance as per the following equation 6. 


$$
R_{i}=\frac{S_{i}^{-}}{S_{i}^{+}+S_{i}^{-}}
$$

Finally, ranking of the biocomposites with maximum Ri, and the values are shown in Table S7.

Table S7. Relative closeness value and ranking.

\begin{tabular}{ccc}
\hline Composites & Relative closeness & Ranking \\
\hline PLA & 0.41 & 4th \\
PLA/5\%TEC & 0.53 & 3rd \\
PLA/10\%TEC & 0.56 & 2nd \\
PLA/15\%TEC & 0.60 & $1 \mathrm{st}$ \\
PLA/MCC & 0.41 & 4th \\
PLA/MCC_5\% TEC & 0.42 & $3 \mathrm{rd}$ \\
PLA/MCC_10\% TEC & 0.58 & $2 \mathrm{nd}$ \\
PLA/MCC_15\% TEC & 0.59 & $1 \mathrm{st}$ \\
\hline
\end{tabular}

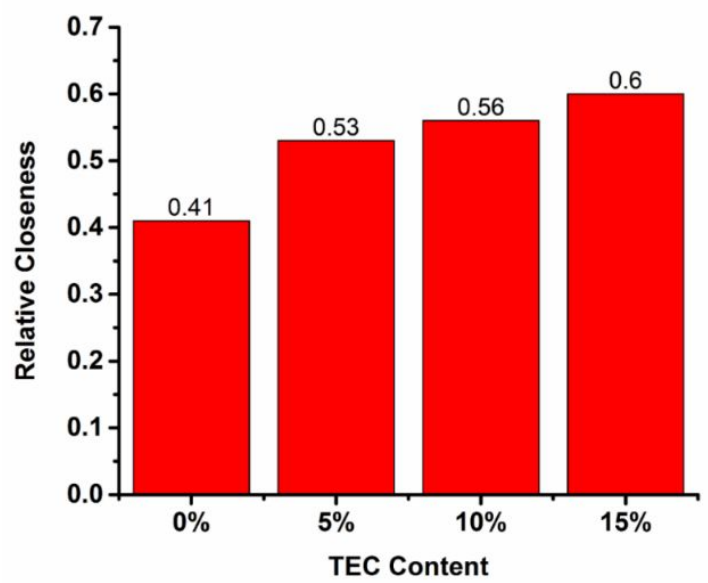

Figure S12. TOPSIS analysis of PLA/TEC blends.

From the TOPSIS analysis, the ranking of PLA/TEC is estimated as, for PLA/TEC: Rank 1 (PLA/15\% TEC), Rank 2 (PLA/10\% TEC), Rank 3 (PLA/5\%TEC), and Rank 4 (PLA). 
Comparison of the performance of PLA/MCC_10\%TEC biocomposites by TOPSIS. To compare the performance of PLA/MCC_10\%TEC biocomposites with other commercial packaging materials, the necessary values are extracted from the literature. ${ }^{5-9}$ Table S8 contains the tensile strength (MPa), Water vapor permeability $\left(\mathrm{g} \cdot \mathrm{mm} / \mathrm{m}^{2} \cdot\right.$ day $\left.\cdot \mathrm{kPa}\right)$, and oxygen permeability $\left(\mathrm{mL} \cdot \mathrm{mm} / \mathrm{m}^{2}\right.$.day.atm) values of commercial packaging materials. . The TOPSIS analysis is carried out by using the below data in Table S8, and the equation stated above. From the TOPSIS analysis, we can see that PLA/MCC_10\%TEC biocomposites can compete with other commercial packaging materials, Figure S13.

Table S8. TOPSIS analysis data set

\begin{tabular}{cccc}
\hline Composites & $\begin{array}{c}\text { Tensile Strength } \\
(\mathrm{Mpa})\end{array}$ & $\begin{array}{c}\text { Water vapor Permeability } \\
\left(\mathrm{g} \cdot \mathrm{mm} / \mathrm{m}^{2} \cdot \mathrm{day} \cdot \mathrm{kPa}\right)\end{array}$ & $\begin{array}{c}\text { Oxygen Permeability } \\
\left(\mathrm{mL} \cdot \mathrm{mm} / \mathrm{m}^{2} . \mathrm{day} \cdot \mathrm{atm}\right)\end{array}$ \\
\hline PLA/MCC_10\% TEC & 11.80 & 12.26 & 6.32 \\
PLA/Cacao_Dry Food & 8.00 & 28.06 & 10.00 \\
EVOH_Fatty Food & 45.00 & 0.04 & 0.01 \\
PP_Frozen food & 36.00 & 0.01 & 75.00 \\
LDPE_Dry Food & 19.50 & 0.02 & 125.00 \\
\hline
\end{tabular}

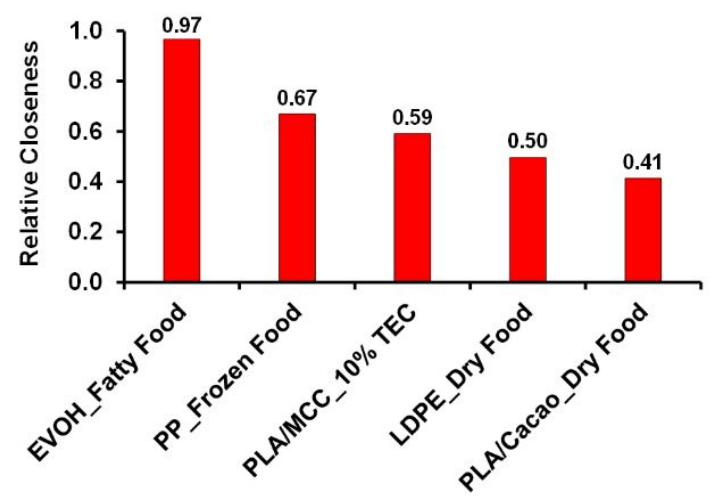


Figure S13. Comparison of the performance analysis of PLA/MCC_TEC composites with other commercial packaging materials.

\section{References.}

1. Park, S.; Baker, J. O.; Himmel, M. E.; Parilla, P. A.; Johnson, D. K., Cellulose crystallinity index: measurement techniques and their impact on interpreting cellulase performance. Biotechnol. Biofuels 2010, 3 (1), 10.

2. Frone, A. N.; Panaitescu, D. M.; Chiulan, I.; Nicolae, C. A.; Vuluga, Z.; Vitelaru, C.; Damian, C. M., The effect of cellulose nanofibers on the crystallinity and nanostructure of poly(lactic acid) composites. J. Mater. Sci. 2016, 51 (21), 9771-9791.

3. Heredia-Guerrero, J. A.; Benítez, J. J.; Cataldi, P.; Paul, U. C.; Contardi, M.; Cingolani, R.; Bayer, I. S.; Heredia, A.; Athanassiou, A., All-Natural Sustainable Packaging Materials Inspired by Plant Cuticles. Adv. Sustainable Syst. 2017, 1 (1-2), 1600024.

4. $\quad$ Arrieta, M. P.; Samper, M. D.; Aldas, M.; López, J., On the Use of PLA-PHB Blends for Sustainable Food Packaging Applications. Mater. 2017, 10 (9).

5. Nanni, G.; Heredia-Guerrero, J. A.; Paul, U. C.; Dante, S.; Caputo, G.; Canale, C.; Athanassiou, A.; Fragouli, D.; Bayer, I. S., Poly(furfuryl alcohol)-Polycaprolactone Blends. Polym. 2019, 11 (6).

6. Papadopoulou, E. L.; Paul, U. C.; Tran, T. N.; Suarato, G.; Ceseracciu, L.; Marras, S.; d'Arcy, R.; Athanassiou, A., Sustainable Active Food Packaging from Poly(lactic acid) and Cocoa Bean Shells. ACS Appl. Mater. Interfaces 2019, 11 (34), 31317-31327.

7. López-de-Dicastillo, C.; Jordá, M.; Catalá, R.; Gavara, R.; Hernández-Muñoz, P., Development of Active Polyvinyl Alcohol/ $\beta$-Cyclodextrin Composites To Scavenge Undesirable Food Components. J. Agric. Food. Chem. 2011, 59 (20), 11026-11033.

8. Luzi, F.; Torre, L.; Kenny, J. M.; Puglia, D., Bio- and Fossil-Based Polymeric Blends and Nanocomposites for Packaging: Structure-Property Relationship. Mater. (Basel) 2019, 12 (3), 471.

9. Wang, J.; Gardner, D. J.; Stark, N. M.; Bousfield, D. W.; Tajvidi, M.; Cai, Z., Moisture and Oxygen Barrier Properties of Cellulose Nanomaterial-Based Films. ACS Sustainable Chem. Eng. 2018, 6 (1), 49-70. 